\title{
Malaysians' Popular Online Shopping Websites during Movement Control Order (MCO)
}

\author{
${ }^{1}$ K. Isa, ${ }^{2}$ J. M. Shah, ${ }^{3}$ S. T. Palpanadan, ${ }^{4}$ F. Isa \\ ${ }^{1 *}, 3$ Universiti Tun Hussein Onn Malaysia \\ ${ }^{2}$ Universiti Malaysia Sabah \\ ${ }^{4}$ Universiti Teknologi Malaysia
}

\section{ABSTRACT}

Movement Control Order (MCO) has been announced since the pandemic of corona virus spread cases increased dramatically. The key point emphasized in the implementation of $\mathrm{MCO}$ is a social distancing where is only one person is allowed to go out to seek daily necessities during daytime. Moreover, only selected essential business is allowed to operate with limited hour from 8 am to $8 \mathrm{pm}$ only. Due to this order, the e-commerce has become an option to most consumers to fulfill their wants and needs. This paper presents the descriptive data that shows the shopping website that has been mostly visited by the consumers during the MCO phase one and phase two and the influencing factors of selected web sites to purchase during MCO. A survey was conducted throughout the country including Sabah and Sarawak using an open-ended questionnaire that was distributed online. A quantitative method with a descriptive research design was adopted to explore the data obtained in relation to the objective of the research. A total number of 280 adults from 14 states provided valid responses to the online questionnaire. The findings show that the top three shopping website that has been visited by the consumers were the Shopee, Lazada and Food Panda that sell general daily necessities needed by the consumers. The findings also showed that the elements of comfortable website referring to the attractive design, friendly user, having a selection of native language, amount of uploaded information and updating of the product details were the factors that contribute towards the attractions of consumers to be involved in online purchasing.

Key words: Movement Control Order (MCO), Websites, Corona virus, Consumers, Trust

\section{INTRODUCTION}

The rapid growth of Internet technology development has enabled consumers to purchase products or services from the web-retailers and search product information over the Internet[1]. Due to the Movement Control Order (MCO) which has been announced during the corona virus pandemic, online shopping has become the most popular business trend not only to the customers but also to trader[2][3][4]. The social distancing that has been stressed in MCO required users or consumers to wait for a long time to buy any goods in physical stores. This situation causes consumers or buyers feel convenient to carry out online shopping. Online shopping gives more benefits to the buyers because they can save their crucial time, become cashless and have a privilege to choose the items[5][6]. The consumers also can find all the items that they want under one roof by using ECommerce platform[7].

The MCO period resulted in a change in consumer behavior in online shopping resulting in the increase in the percentage of sales not only involving the daily necessities of goods, but also involving other items such as electrical appliances, jewelries and clothing[8]. According to many online traders such as Happy Fresh and Lazada, their sales have increased during MCO period (up to 10-15\%) from the normal daily business[4]. Meanwhile, other online traders such as Mydin Mart, Tesco Online, Lazada, My Grocer, and Happy Fresh are expressing that the goods with high demand are not only for daily needs but also include the merchandise equipment and computer accessories due to the concept of working from home applied since the implementation of MCO.

\section{LITERATUREREVIEW}

Good line coverage, fast internet access and good services provided by the trades are some of the factors that contributed to the pattern of online shopping among Malaysian consumers[9][10][11]. A survey on the Internet User in 2017 conducted by the Communication Commission and Multimedia Malaysia (MCMC, 2017) shows that the Internet users in 2016 were 24.5 million with smart phone becoming the main tool used to surf the Internet[12]. In addition, the increasing of marketing ads on the social media also affect the decisionmaking of the consumers [13]. Participation in electronic commerce or e-commerce has also increased up to $48.8 \%$ with online bank transfer which is the most commonly used payment method in Internet purchase transaction in 2016[14]. Therefore, more consumers are become increasingly familiar with the internet. Thus, online shopping is becoming popular and getting preference among groups of consumers seeking better value proposition regarding information, convenience, costs and choice[15].

Online shopping has many benefits to consumers. Consumers can access the goods that they want to buy in 24 hours. Therefore, they have a lot of time to make a decision to buy, can access worldwide store, have home delivery services and even 
can cancel the purchase before making the payment. All goods in the online store are described through text with attractive photo. They are user friendly and have many uploaded multimedia files. Many stores will provide link for extra information about their products and some of the stores provide testimony from previous buyers as evidence for their good services. According to Forsythe et al., the variety of online goods and services allows users to make choice and have freedom from social disruption and this will increase the satisfaction of the customers[16].

In the context of traders, the main goal of their business is to offer the best product and services which can fulfill the customers' needs. It is because the business which can fulfill the customers' needs with satisfaction becomes more successful and will allow buyer to repeat purchases. Shergill and Chen added that, the online traders, on the other hand, need to focus on the website design, friendly customer service and website security which are the users' priority in choosing business websites on the internet to perform transactions[17][18]. In addition, based on the study conducted by Lee and Lin, to promote online purchasing among consumers, traders need to make sure the website designed is simple and convenient for users to make a purchase[19]. Meanwhile, a user-friendly website with interesting graphical display and complete menu selection of options will help customers to search the desired products or services that they are looking for[19]. According to Blanca et al., it is important for traders to maintain their website actively to suit the customers' needs because this perception will induce individuals to purchase online for the first time which may not be the same as those who have repurchasing behavior[20].

Positive feedback from customers related to the sales services provided by traders is an important appreciation to maintain the business in the market[21]. This fact has been proven by Wolfinbarger and Gilly who found that the quality in the service is very important in measuring customer satisfaction towards online purchasing of goods[22]. At the same time, the customer satisfaction will actually affect future purchases whether to repeat order with the same trader or not. However, the Park et al., claim that it is difficult to get feedback from customers especially concerning the quality of goods[23]. Therefore, online traders must practice honesty and transparent attitude by offering items that are good based on the demand from consumers.

\section{METHODOLOGY}

This study was conducted using quantitative approach by distributing the study instrument to the respondents via Google Form[24]. A total of 280 Malaysians around Malaysia including Sabah and Sarawak were involved in this survey. The survey was conducted to identify the most popular shopping website that has been visited during MCO phase I and II; the website selection factors and the frequency and the types of goods purchased before MCO and during MCO. This research employed a self-developed questionnaire with four Likert scale as the research instrument which is: $1=$ Strongly Not Agree, $2=$ Not Agree, $3=$ Agree and 4=Strongly Agree. The development of the items was referred to the previous quantitative and qualitative research. There are three sections in the questionnaire as per description in Table 1. All the items will be analyzed descriptively using SPSS version 24 .

Table 1: Item in the Questionnaire

\begin{tabular}{|c|c|l|c|}
\hline Num & Section & \multicolumn{1}{|c|}{ Description } & $\begin{array}{c}\text { Number } \\
\text { of item }\end{array}$ \\
\hline 1 & Section A: & Demography & 11 \\
\hline 2 & Section B: & $\begin{array}{l}\text { Most website } \\
\text { visited }\end{array}$ & 7 \\
\hline 3 & Section C: & $\begin{array}{l}\text { Website selection } \\
\text { factor to buy }\end{array}$ & 7 \\
\hline \multicolumn{3}{|c|}{ Total } & $\mathbf{2 5}$ \\
\hline
\end{tabular}

\section{FINDINGS AND DISCUSSION}

This study involved 280 consumers from all over Malaysia. A total of $144(51.4 \%)$ of them are men and the rest of the 136 $(48.6 \%)$ are women. The majority of the respondents are Malays where the total respondents were 211 (75.4\%), followed by other $31(11.1 \%)$ respondents, $30(10.7 \%)$ Chinese respondents and $8(2.9 \%)$ Indian respondents. Teenagers, aged between $15-24$ years old are the most number of respondents involved in online purchasing which is 216 (77.1\%) respondents, followed by adults in average aged between 25 to 34 years old $(n=27,9.6 \%)$ and only a small number $(n=12$, $4.3 \%$ ) who were actively engaged in online purchasing. 74 (26.4\%) of the respondents involved in online purchasing was in Johor (the highest) and Selangor and Sabah respectively had 36 respondents $(12.9 \%)$ each. Meanwhile, Pulau Pinang $(\mathrm{n}=9$, $3.2 \%)$, Pahang $(\mathrm{n}=8,2.9 \%)$, Wilayah Persekutuan $(\mathrm{n}=7,2.5 \%)$ and Perlis $(n=1,0.4 \%)$ have a small number of respondents which is less than 10. Based on the data, most of the students $(\mathrm{n}=214,76.4 \%)$ were involved actively in online purchasing during MCO, followed by civil servants $(n=34,12.1 \%)$. These two categorizes were probably involved in online purchasing during MCO because of the implementation of online classes for teaching and learning for students and working from home concept for civil servants. The details of the respondents' demographic are as per description in Table 2.

Table 2: Respondents' Demographic Information

\begin{tabular}{|c|c|c|}
\hline & $\begin{array}{c}\text { Frequency } \\
\text { (F) }\end{array}$ & $\begin{array}{c}\text { Percentage } \\
(100 \%)\end{array}$ \\
\hline \multicolumn{3}{|l|}{ Gender } \\
\hline Male & 144 & 51.4 \\
\hline Female & 136 & 48.6 \\
\hline Total & 280 & 100.0 \\
\hline \multicolumn{3}{|l|}{ Ethnic } \\
\hline Malay & 211 & 75.4 \\
\hline Chinese & 30 & 10.7 \\
\hline Indian & 8 & 2.9 \\
\hline Others & 31 & 11.1 \\
\hline Total & 280 & 100.0 \\
\hline \multicolumn{3}{|l|}{ Age } \\
\hline $15-24$ years & 216 & 77.1 \\
\hline $25-34$ years & 27 & 9.6 \\
\hline $35-44$ years & 25 & 8.9 \\
\hline $45-59$ years & 12 & 4.3 \\
\hline Total & 280 & 100.0 \\
\hline State & & \\
\hline
\end{tabular}




\begin{tabular}{|l|c|c|}
\hline Perlis & 1 & .4 \\
\hline Kedah & 13 & 4.6 \\
\hline Pulau pinang & 9 & 3.2 \\
\hline Perak & 15 & 5.4 \\
\hline Selangor & 36 & 12.9 \\
\hline Wilayah Persekutuan & 7 & 2.5 \\
\hline Negeri Sembilan & 13 & 4.6 \\
\hline Melaka & 18 & 6.4 \\
\hline Johor & 74 & 26.4 \\
\hline Kelantan & 22 & 7.9 \\
\hline Terengganu & 11 & 3.9 \\
\hline Pahang & 8 & 2.9 \\
\hline Sabah & 36 & 12.9 \\
\hline Sarawak & 17 & 6.1 \\
\hline & $\mathbf{2 8 0}$ & $\mathbf{1 0 0 . 0}$ \\
\hline Occupancy & & \\
\hline Student & 214 & 76.4 \\
\hline House wife & 2 & .7 \\
\hline Entrepreneur & 3 & 1.1 \\
\hline Private Sector & 22 & 7.9 \\
\hline Government Sector & 34 & 12.1 \\
\hline Not working Total & 5 & 1.8 \\
\hline \multicolumn{280}{|c|}{} & \\
\hline
\end{tabular}

respondents (253 of them) tend to choose websites which have attractive designs to browse. According to the respondents, they need a comfortable website to make a choice for their selection of items during purchasing. Therefore, nearly half of them (107 respondents) would ensure that there is no interruption or pop-up while browsing the shopping websites. However, some of the respondents $(\mathrm{f}=101)$ do not seem to mind the interruption or popup when browsing the websites.

Most of the respondents ( $\mathrm{f}=245)$ stated that they will choose the shopping websites which keep updating the new information of their products and have a variety of languages to choose $(f=254)$ because it will help buyers to understand better in their native languages. Another factor which contributes to consumer browsing is when the websites provide the testimony from previous customers. Most of the respondents $(\mathrm{f}=238)$ agree that they prefer websites which display testimony from previous customer so they will take it as a reference before they conduct any sales and purchase activities.

However, other factors that influence consumers to choose the websites to repeat their order involve the elements of trust and integrity during the sales and purchase activities. The findings show that a total of 146 out of 280 respondents agreed that throughout the online purchase, they often face the situation

Table 3 shows the most popular shopping websites that have been visited during MCO phase I and II. The analyses showed that the three most popular shopping websites that have been visited were Shopee Malaysia with 166 choices from respondents followed by Lazada ( $\mathrm{f}=45$ ) and Food Panda $(\mathrm{f}=26)$. This finding is in contrast with the findings of the study conducted by Alexa and Similarweb website which found that Lazada was the most popular website visited by the customers with a total monthly trafficking of 24.68 million visitors followed by Shopee at ranking number two with the monthly trafficking of 21.05 million visitors. Meanwhile, Food Panda (the mobile delivery food market) was ranked at the third place in this survey. It can be assumed that food panda which was running famously in Malaysia in 2019 become a choice of website among eaters who are limited to having their favorite food during this MCO. The data also showed that the popularly visited shopping websites were the platforms, which offer daily necessities and current items as well.[25][26]

Table 3: The Popular Websites Visited by Consumers during

\begin{tabular}{|c|l|c|c|}
\hline Num & \multicolumn{1}{|c|}{ Item } & Frequency & Percent \\
\hline 1 & Lazada & 45 & 16.1 \\
\hline 2 & Mudah.my & 3 & 1.1 \\
\hline 3 & 11 street Malaysia & 1 & .4 \\
\hline 4 & Lelong Malaysia & 1 & .4 \\
\hline 5 & Shopee Malaysia & 166 & 59.3 \\
\hline 6 & Zalora & 5 & 1.8 \\
\hline 7 & Fashion Valet & 1 & .4 \\
\hline 8 & Food Panda & 26 & 9.3 \\
\hline 9 & Tudung2u Online & 1 & .4 \\
\hline 10 & Amazon.com & 1 & .4 \\
\hline 11 & Lain-lain & 30 & 10.7 \\
\hline & & $\mathbf{2 8 0}$ & $\mathbf{1 0 0 . 0}$ \\
\hline
\end{tabular}

Based on Table 4, the data show that the majority of the where the product displayed is not the same with the actual product sold. This situation may affect consumers' trust towards the website and might not to repeat order in the future. According to Blanca et al., the perceptions that induce individuals to purchase online for the first time may not be the same of the repurchasing behavior[20]. However, most consumers are concerned about the trust and the security of the overall online shopping matters [23][27].

Table 4: Factor Influencing the Selection of Website

\begin{tabular}{|c|c|c|c|c|c|}
\hline num & Item & STA & NA & $\mathbf{A}$ & SA \\
\hline 1 & $\begin{array}{l}\text { Website has } \\
\text { an attractive } \\
\text { designed. }\end{array}$ & $\begin{array}{c}3 \\
(1.1 \%)\end{array}$ & $\begin{array}{c}24 \\
(8.6 \%)\end{array}$ & $\begin{array}{c}199 \\
(71.1 \%)\end{array}$ & $\begin{array}{c}54 \\
(19.3 \%)\end{array}$ \\
\hline 2 & $\begin{array}{l}\text { No others } \\
\text { interruption } \\
\text { advertisement } \\
\text { / pop - up } \\
\text { during } \\
\text { browsing the } \\
\text { shopping } \\
\text { website }\end{array}$ & $\begin{array}{c}44 \\
(15.7 \%)\end{array}$ & $\begin{array}{c}101 \\
(36.1 \%)\end{array}$ & $\begin{array}{c}107 \\
(38.2 \%)\end{array}$ & $\begin{array}{c}28 \\
(10 \%)\end{array}$ \\
\hline 3 & $\begin{array}{l}\text { Website keep } \\
\text { update with } \\
\text { new } \\
\text { information of } \\
\text { product }\end{array}$ & $\begin{array}{c}2 \\
(0.7 \%)\end{array}$ & $\begin{array}{c}33 \\
(11.8 \%)\end{array}$ & $\begin{array}{c}177 \\
(63.2 \%)\end{array}$ & $\begin{array}{c}68 \\
(24.3 \%)\end{array}$ \\
\hline 4 & $\begin{array}{l}\text { Website have } \\
\text { a variety of } \\
\text { languages to } \\
\text { choose }\end{array}$ & $\begin{array}{c}1 \\
(0.4 \%)\end{array}$ & $\begin{array}{c}25 \\
(8.9 \%)\end{array}$ & $\begin{array}{c}178 \\
(63.6 \%)\end{array}$ & $\begin{array}{c}76 \\
(27.1 \%)\end{array}$ \\
\hline 5 & $\begin{array}{l}\text { I prefer to } \\
\text { browse } \\
\text { website with } \\
\text { testimony } \\
\text { from previous } \\
\text { customer }\end{array}$ & $\begin{array}{c}5 \\
(1.8 \%)\end{array}$ & $\begin{array}{c}37 \\
(13.2 \%)\end{array}$ & $\begin{array}{c}132 \\
(47.1 \%)\end{array}$ & $\begin{array}{c}106 \\
(37.9 \%)\end{array}$ \\
\hline
\end{tabular}




\begin{tabular}{|c|l|c|c|c|c|}
\hline 6 & $\begin{array}{l}\text { Throughout } \\
\text { the online } \\
\text { purchase, I } \\
\text { often face the } \\
\text { situation } \\
\text { which the } \\
\text { product } \\
\text { displayed not } \\
\text { the same with } \\
\text { the actual } \\
\text { product }\end{array}$ & $\begin{array}{c}117 \\
(41.8 \%)\end{array}$ & $\begin{array}{c}125 \\
(44.6 \%)\end{array}$ & $\begin{array}{c}21 \\
(7.5 \%)\end{array}$ & 4. \\
\hline 7 & $\begin{array}{l}\text { I often } \\
\text { encountered a } \\
\text { problem while } \\
\text { browsing the } \\
\text { website } \\
\text { because is not } \\
\text { user friendly }\end{array}$ & 39 & 135 & 86 & 20 \\
$(13.9 \%)$ & $(48.2 \%)$ & $(30.7 \%)$ & $(7.1 \%)$ \\
\hline
\end{tabular}

\section{CONCLUSION}

In conclusion, most Malaysian online shoppers are students aged between 15 to 24 years old who are actively involved in online shopping. While, respondents in Johor was the highest involved in online purchasing. During this MCO, the top three shopping websites visited by the consumers were Shopee, Lazada and Food Panda where all three websites sell general daily necessities and current items as well. It can be assumed that, limited movement due the MCO implementation has influenced consumers to buy basic need products via online. Furthermore, most of the respondent look for attractive web design and friendly user website provided by the online traders because it will affect their mood to choose the items that they really want. Besides, most of the respondents rely on helpful websites which are full of useful information and will ensure that the elements of security are highly practised by the websites they browse.

In the trader's point of view, understanding the types of consumers and the most popular goods that the consumers are looking for are the strategies to compete in the market[28]. In addition, being alert with current incident that might happen in the country will help traders to plan for the solutions needed by the consumers. Apart from that, the element of trust and honesty should be practised during the sales and purchase activities to build trust among the consumers[29]. Thus, it may become the best online shopping website that the trader could provide so that the repetition of order could be increased remarkably.

\section{REFERENCES}

1. Kwek CL, Tan HP, Lau T-C. Investigating the shopping orientations on online purchase intention in the e-commerce environment: a Malaysian study. $J$ Internet Bank Commer. 1970;15(2):1-21.

2. Nurul Hidayah Bahaudin. Beli-belah secara "online" rancak ketika PKP [Internet]. MyMetro. 2020 [cited 2020 Apr 20]. Available from: https://www.hmetro.com.my/mutakhir/2020/03/558385/b eli-belah-secara-online-rancak-ketika-pkp

3. Zumbach L. Covid-19: Online shopping won't get you hard-to-find items during coronavirus pandemic [Internet]. The Star Online. 2020 [cited 2020 Apr 20]. Available from: https://www.thestar.com.my/tech/technews/2020/03/31/covid-19-online-shopping-wont-getyou-hard-to-find-items-during-coronavirus

4. Bernama. Covid-19: Pembelian "online" melonjak [Internet]. MyMetro. 2020 [cited 2020 Apr 20]. Available from:

https://www.hmetro.com.my/mutakhir/2020/03/557138/co vid-19-pembelian-online-melonjak

5. Yazid Z, Wel CAC, Omar NA. Persepsi Mahasiswa Terhadap Urusan Pembelian Atas Talian. J Pers Pelajar. 2016;9.

6. Islam MA, Daud KAK. Factors that influence customers' buying intention on shopping online. Int $J$ Mark Stud. 2011;3(1):128.

https://doi.org/10.5539/ijms.v3n1p128

Saeed S, Naqvi M, Memon M. E-Commerce Web Crawling to Facilitate Consumers for Economical Choices.Int J Adv Comput Syst Softw Eng. 2020;1(1):113.

8. Saiful Irwan Zubairi. COVID-19: Permintaan tinggi produk mudah-sedia, jejaskan operasi pengilang. Berita Harian Online. 2020.

9. Adnan H. An analysis of the factors affecting online purchasing behavior of Pakistani consumers. Int $J$ Mark Stud. 2014;6(5):133.

https://doi.org/10.5539/ijms.v6n5p133

10. Aldridge A, Forcht K, Pierson J. Get linked or get lost: marketing strategy for the Internet. Internet Res. 1997;

11. Azmi NF, Peng LW. Factors Influencing the Intention for Online Purchasing: a Study among University Students in Malaysia.Int J Manag. 2014;4(2):69-74.

12. Malaysia CC and M. Internet Users Survey 2017. 2017; Available from: https://www.mcmc.gov.my/skmmgovmy/media/General/p df/MCMC-Internet-Users-Survey-2017.pdf

13. Tseng C-H, Wei L-F. The efficiency of mobile media richness across different stages of online consumer behavior. Int J Inf Manage. 2020;50:353-64.

https://doi.org/10.1016/j.ijinfomgt.2019.08.010

14. Lohse GL, Spiller P. Electronic shopping. Commun ACM. 1998;41(7):81-7.

https://doi.org/10.1145/278476.278491

15. Mutum D, Ghazali E. Online shoppers vs non-shoppers: a lifestyle study of Malaysian Internet users. Proc $A d v$ Glob Bus Res. 2006;166-76.

16. Forsythe S, Liu C, Shannon D, Gardner LC. Development of a scale to measure the perceived benefits and risks of online shopping. J Interact Mark. 2006;20(2):55-75.

17. Shergill GS, Chen Z. Web-Based Shopping: Consumers' attitudes Towards Online Shopping In New Zealand. J Electron Commer Res. 2005;6(2):78.

18. Mizan NSM, Ma'arif MY, Satar NSM, Shahar SM. Cndscybersecurity: Issues and challenges in asean countries.Int J Adv Trends Comput Sci Eng. 2019;8(1.4 S1):113-9.

https://doi.org/10.30534/ijatcse/2019/1781.42019

19. Lee G, Lin H. Customer perceptions of e $\square$ service quality in online shopping.Int $J$ Retail Distrib Manag. 2005; 
20. HernáNdez B, JiméNez J, Martín MJ. Key website factors in e-business strategy.Int $J$ Inf Manage. 2009;29(5):362-71.

21. Román S, Riquelme IP. Personal Determinants of Online Shopping Frustration and Its Influence on Consumers'positive Word of Mouth. $J$ Electron Commer Res. 2014;15(2):87.

22. Wolfinbarger M, Gilly MC. Shopping online for freedom, control, and fun. Calif Manage Rev. 2001;43(2):34-55.

https://doi.org/10.2307/41166074

23. Park D-H, Lee J, Han I. The effect of on-line consumer reviews on consumer purchasing intention: The moderating role of involvement. Int $J$ Electron Commer. 2007;11(4):125-48.

24. Vijayakumari R, Kirankumar R, Rao KG. Comparative analysis of google file system and hadoop distributed file system. Int $J$ Adv Trends Comput Sci Eng. 2014;3(1):553-8.

25. Alexa. The top 500 sites on the web [Internet]. Amazon.com. 2020 [cited 2020 Apr 20]. Available from: https://www.alexa.com/topsites

26. Top Websites Ranking [Internet]. SimilarWeb. [cited 2020 Apr 20]. Available from: https://www.similarweb.com/topwebsites/malaysia/category/e-commerce-and-shopping/

27. Rahman MA, Islam MA, Esha BH, Sultana N, Chakravorty S. Consumer buying behavior towards online shopping: An empirical study on Dhaka city, Bangladesh. Cogent Bus Manag. 2018;5(1):1514940. https://doi.org/10.1080/23311975.2018.1514940

28. Kolesar MB, Galbraith RW. A services $\square$ marketing perspective on retailing: implications for retailers and directions for further research.Internet Res. 2000; https://doi.org/10.1108/10662240010349444

29. Khan F, Rasli A, Yusoff R, Isa K. Impact of Trust on Online Shopping: A Systematic Review of Literature. J Adv Rev Sci Res. 2015;8(1):1-8. 